\title{
Experimental recolonisation of Baltic Sea reduced sediments: survival of benthic macrofauna and effects on nutrient cycling
}

\author{
Karin Karlson $^{1, *}$, Stefan Hulth ${ }^{2}$, Katja Ringdahl ${ }^{3}$, Rutger Rosenberg ${ }^{3}$ \\ ${ }^{1}$ Göteborg University, Department of Marine Ecology, Marine Botany, Box 461, 40530 Göteborg, Sweden \\ ${ }^{2}$ Göteborg University, Department of Chemistry, 41296 Göteborg, Sweden \\ ${ }^{3}$ Göteborg University, Department of Marine Ecology, Kristineberg Marine Research Station, 45034 Fiskebäckskil, Sweden
}

\begin{abstract}
A recolonisation experiment was performed in vitro on highly reduced laminated Baltic Sea sediments initially devoid of larger benthic fauna. The survival capacity of 3 common benthic species Monoporeia affinis, Macoma balthica and Marenzelleria viridis was investigated along with overall effects of bioturbation and bioirrigation on benthic reaction and transport processes. Benthic fluxes of oxygen and nutrients, sediment denitrification and nutrients in the porewater were measured. Survival of $M$. affinis increased with time and sediment reworking, while no such feedback was observed for $M$. balthica and $M$. viridis. Macrofaunal irrigation and bioturbating activities significantly enhanced solute fluxes in the manipulated cores compared to the control. Mass balance calculations indicated that net $\mathrm{N}$-mineralisation in the manipulated cores was stimulated by 1 to 2 orders of magnitude compared to the control. Despite relatively high nitrate fluxes from the overlying water to the sediment $\left(\sim 1 \mathrm{mmol} \mathrm{m}^{-2} \mathrm{~d}^{-1}\right)$, measured rates of total denitrification were in general low (20 to $45 \mu \mathrm{mol} \mathrm{N} \mathrm{m}^{-2} \mathrm{~d}^{-1}$ ) in all cores. Denitrification, using nitrate supplied from the overlying water $\left(D_{\mathrm{w}}\right)$, was similar to coupled nitrification/denitrification $\left(D_{n}\right)$, although $D_{w}$ was significantly higher than $D_{n}$ in the $M$. affinis cores. In conjunction with high nitrate fluxes into the sediment and high ammonium fluxes to the overlying water, the generally low denitrification rates indicated dissimilatory nitrate reduction to ammonium (DNRA) as the main pathway for nitrate removal. Thus, the main source of bottom water ammonium was overlying water nitrate, rather than ammonium produced in surface sediments during mineralisation of organic $\mathrm{N}$.
\end{abstract}

KEY WORDS: Recolonisation $\cdot$ Bioturbation $\cdot$ Macrofauna $\cdot$ Baltic Sea $\cdot$ Reduced sediments Benthic fluxes $\cdot$ Denitrification $\cdot$ Mineralisation

\section{INTRODUCTION}

Below 70 to $80 \mathrm{~m}$ water depth, large areas $(70000$ to $100000 \mathrm{~km}^{2}$ ) of Baltic Sea sediments have no or significantly reduced numbers of sediment-dwelling macrofauna due to hypoxic $\left(<100 \mu \mathrm{M} \mathrm{O}_{2}\right.$ or $\left.<2 \mathrm{ml} \mathrm{O}_{2} \mathrm{l}^{-1}\right)$ or anoxic conditions and the presence of $\mathrm{H}_{2} \mathrm{~S}$ (Elmgren 1989, Jonsson et al. 1990). Anoxia and hypoxia also have significant ecological impacts on sediments of the Baltic Sea archipelago, often exemplified by laminated sediments devoid of larger fauna (Bonsdorff et al. 1996, Persson \& Jonsson 2000). Several studies have related this to an accelerated nutrient discharge and coastal eutrophication, in combination with a restricted water inflow of well-oxygenated, high-salinity bottom water from the Kattegatt/North Sea area (reviewed in Karlson et al. 2002). Overall, the Baltic Sea is a highly stratified and enclosed basin with a significant fresh-water input. During periods with external water supply or vertical mixing across density surfaces, however, improved oxygen conditions close to the sedimentwater interface open possibilities for recolonisation by benthic organisms (Leppäkoski 1971, Gerlach 1994, Laine et al. 1997). It is known that oxygen availability 
in the bottom water is a main factor controlling benthic faunal composition and abundance in stratified and enclosed waters (Diaz \& Rosenberg 1995).

According to parameters such as feeding mode, position and mobility in the sediment, construction, solute irrigation and particle disruption, benthic fauna can be classified into functional groups (Pearson \& Rosenberg 1987, Bonsdorff \& Pearson 1999). These functions are key parameters that constrain the feed-back mechanisms likely to operate between macrofaunal activities and organic matter mineralisation in surface sediments (Diaz \& Schaffner 1990, Boudreau 1997, Gilbert et al. 2003). Sediment reworking and pore-water irrigation by re-colonising benthic fauna will enhance the overall transport of organic and inorganic particles (including particle-associated oxidants, e.g. Fe- and Mn oxides), as well as dissolved constituents (e.g. oxygen and nutrients) between the sediment and overlying bottom water (e.g. Aller \& Yingst 1985, Aller 2001). In addition, faunal activities in the surface sediment vertically and horizontally redistribute particulate material within the sediment matrix, alter the surface to volume ratio of particles, and expose new surfaces for microbial colonisation (Aller \& Aller 1998). For example, activities by natural densities of Corophium volutator (Hyllenberg \& Henriksen 1980) and Nereis virens (Kristensen et al. 1991) were estimated to increase the volume of oxic surface sediment by 30 to $50 \%$ and 100 to $150 \%$, respectively. Frequent irrigation of burrows and tube constructions not only increases the supply of oxygen and other solutes to the surface sediment layer, but also improves general conditions for benthic organisms by removing toxic metabolites (e.g. $\mathrm{NH}_{4}{ }^{+}$and $\mathrm{HS}^{-} / \mathrm{H}_{2} \mathrm{~S}$ ) and alters the diffusional geometry of the sediment structure (Hulth et al. 1999, Aller 2001, Gilbert et al. 2003). Benthic macrofauna may also affect the general characteristics of the microenvironment by promoting oscillating sediment redox conditions, grazing microbes and excreting important $\mathrm{N}$-nutrients such as ammonium and urea (Mayer et al. 1995, Hulthe et al. 1997, Aller \& Aller 1998).

Nitrogen mineralisation pathways and transport of $\mathrm{N}$-containing organic and inorganic solutes across the sediment-water interface largely depends on the redox conditions of the bottom water and surface sediment layers. Pore water mobilisation of $\mathrm{NH}_{4}{ }^{+}$is due to the combined effects of organic matter hydrolysis and mineralisation of monomeric units, degradation of organic molecules (e.g. urea) excreted by the macrofauna, and direct animal excretion of ammonium (Blackburn 1983, Magni et al. 2000). In certain environments, ammonium is produced by dissimilatory nitrate reduction (DNRA), a process that appears (at least) as important as denitrification for total $\mathrm{NO}_{3}{ }^{-}$ reduction in environments with high rates of carbon mineralisation, e.g. fish farm sediments (Hattori 1983, Christensen et al. 2000). However, DNRA is generally considered to be less important in sediments with a low to moderate supply of organic material. In aerobic surface sediments, ammonium is preferentially oxidised to nitrite and nitrate during nitrification (Ward 2000). Nitrification is normally inhibited during a restricted oxygen supply or in completely anoxic environments; however, there are recent observations of ammonium oxidation to either nitrate (Hulth et al. 1999, Anschutz et al. 2000) or $\mathrm{N}_{2}$ in anaerobic sediments (Luther et al. 1997, Hulth et al. 2004).

As denitrification is inhibited in the presence of oxygen, denitrification is restricted to low oxygen or anoxic environments. While nitrification and denitrification seem mutually exclusive with respect to $\mathrm{O}_{2}$ requirements, the often sharp gradients of $\mathrm{O}_{2}, \mathrm{NH}_{4}{ }^{+}$, and $\mathrm{NO}_{3}{ }^{-}$in surface sediments allow them to operate in close proximity to each other. Sediment-inhabiting animals frequently have far-reaching effects on the shape and extent of the oxic-anoxic interface, often significantly stimulating organic matter mineralisation and promoting sharp gradients across linings of burrow constructions (Brune et al. 2000, Hulth et al. 2002). The combined activities of benthic fauna may thus have significant effects on the form and amount of $\mathrm{N}$ that is mobilised to the pore water and subsequently released to the overlying water. For example, field (e.g. Mayer et al. 1995, Gilbert et al. 1998, Gran \& Pitkänen 1999) and laboratory studies (e.g. Kristensen et al. 1991, Pelegrí et al. 1994, Svensson \& Leonardson 1996) have shown that benthic animals strongly influence both nitrification and denitrification, as well as the coupling between the 2 processes, the reduction of nitrate and nitrite to dinitrogen gas. In general, there is a stimulatory effect of macrobenthic activity on both sedimentary nitrification and denitrification (e.g. Pelegrí et al. 1994, Mayer et al. 1995, Gilbert et al. 1998). From studies in the Baltic Sea region, Gran \& Pitkänen (1999) found that benthic denitrification was stimulated in certain areas in the Gulf of Finland, which are dominated by Monoporeia affinis and Pontoporeia femorata (amphipods). However, measurements have also demonstrated that denitrification rates may vary inversely with bioirrigation intensity at the highest irrigation rates due to more or less complete oxygenation of surface sediments (Gilbert et al. 2003). Direct comparison of causes and magnitudes of reported stimulation (from $2 \times$ to $>10 \times$ ) or inhibition is virtually impossible because macrofaunal abundance, species and species diversity are distinct to the specific environment of each study, and require characterisation at a level of species functionality.

Following deposition of organic material to the sediment surface, sediments may be either sources or sinks 
of various phosphorus fractions (Larsson et al. 1985, Sundby et al. 1986, Carman \& Jonsson 1991). Wulff \& Stigebrandt (1989) estimated that approximately $60 \%$ of the total annual P load to the Baltic Sea is trapped in the sediment. More or less permanent sediment removal of phosphorus is mainly due to the burial of organic and inorganic fractions resistant to degradation, while biologically available phosphorus released to the pore water during organic matter mineralisation may be readily adsorbed onto iron oxy-hydroxides in oxic sediments (Krom \& Berner 1980, Thamdrup 2000), or assimilated into the microbial community. The latter processes are normally reversible in the sense that organic and inorganic phosphorus may be released and recycled to the pore water during shorter time scales following desorption and mineralisation of organic matter. Due to the direct link between availability of oxidants such as oxygen and nitrate in the bottom water and surface sediment layers, and the mobility and remobilisation of phosphorus, activities of benthic macrofauna are often correlated to benthic phosphate fluxes and concentrations of phosphate in the pore water (Tuominen et al. 1999).

The overall aim of this work was to imitate a macrofaunal recolonisation event in Baltic Sea sediments in vitro. Improved benthic redox conditions following the continuous renewal of oxygenated near-bottom water were mimicked during laboratory sediment-water incubations using intact (unsieved), laminated, anoxic (black with a distinct smell of hydrogen sulphide) sediment from the Baltic Sea. The capacity for benthic macrofauna to survive recolonisation and effects of faunal function on overall benthic processes during early diagenesis were investigated for 3 common species of macrofauna. Pore water mobilisation and benthic solute fluxes $\left(\mathrm{NH}_{4}{ }^{+}, \Sigma \mathrm{NO}_{3}{ }^{-}+\mathrm{NO}_{2}{ }^{-}, \mathrm{HPO}_{4}{ }^{2-}\right.$, $\left.\mathrm{Si}(\mathrm{OH})_{4}\right)$ were determined along with direct measurements of sediment denitrification (the isotope pairing technique).

\section{MATERIALS AND METHODS}

Macrofaunal species. The species Monopereia affinis, Macoma balthica and Marenzelleria viridis were chosen for this experiment mainly because they represent different functional groups of macrofauna (Bonsdorff \& Pearson 1999), and are all common and important bioturbators in Baltic Sea sediments (Zettler 1997, Laine 1999, Olenin \& Leppäkoski 1999) (Fig. 1).

Monopereia affinis is a deposit-feeding amphipod that ingests particles mainly on the sediment surface (Lopez \& Elmgren 1989). Although most individuals are normally found in the upper $5 \mathrm{~cm}$ of the sediment, they can burrow to a depth of at least about $10 \mathrm{~cm}$ (Hill

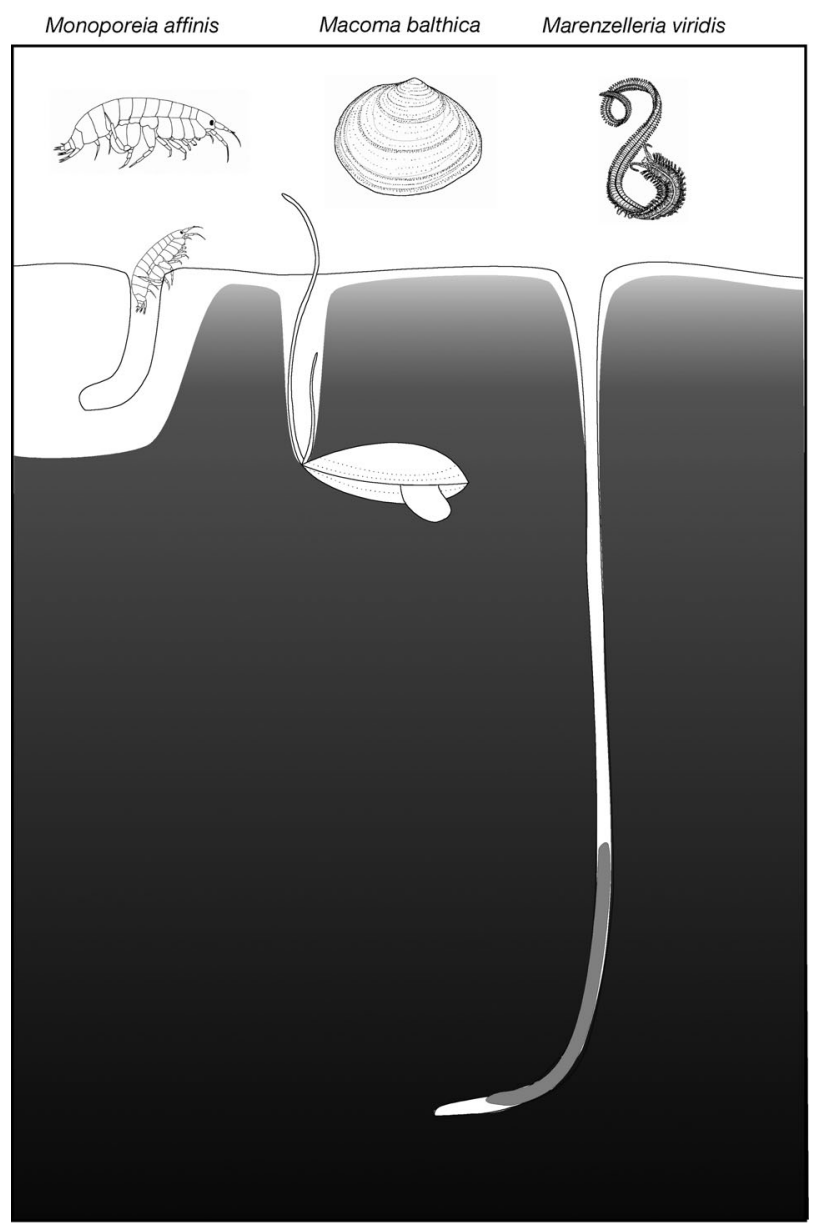

Fig. 1. Monoporeia affinis, Macoma balthica and Marenzelleria viridis. The average position in the sediment of 3 common species of bioturbating fauna in the Baltic Sea. The grey-scale of the sediment is used to indicate the 2-dimensional oxygenation in the proximity to the animal constructions. Illustrations are by M. L. Enckell and P. H. Zettler

\& Elmgren 1987). M. affinis exhibits nocturnal swimming activity, and may in this way be carried to a new area with the horizontally-moving bottom-water current (Lindström 1991). Macoma balthica is a depositand suspension-feeding bivalve, normally positioned about $5 \mathrm{~cm}$ into the sediment (Ólafsson 1986, Rumohr et al. 1996). Marenzelleria viridis is a burrowing polychaete introduced to the Baltic Sea during the 1980s (Zettler 1997, Olenin \& Leppäkoski 1999). M. viridis builds L-shaped and non-ramified burrows that may extend down to a depth of about $35 \mathrm{~cm}$ (Zettler et al. 1994 in Zettler 1997).

Adult Macoma balthica and Marenzelleria viridis do not migrate into the water column. These species are therefore normally not able to colonise new areas in the same way as the amphipod Monopereia affinis. However, we used the species combination $M$. balthica, $M$. viridis and $M$. affinis due to their individual 
functional characteristics and consecutive behaviour following colonisation of laminated surface sediments.

Sampling and benthic flux measurements. In July 2000 , sediment cores (inner diameter of $8 \mathrm{~cm}$ ) were collected by a Gemini sampler in the Kanholmsfjärden (outer Stockholm archipelago; 93 to $97 \mathrm{~m}$ water depth; $59^{\circ} 20^{\prime} 19$ to $97^{\prime \prime}, 18^{\circ} 46^{\prime} 62$ to $76^{\prime \prime}$ ) using the RV 'Sunbeam'. The bottom-water temperature was 4.3 to $6.5^{\circ} \mathrm{C}$, the salinity was $8 \%$, and the oxygen concentration varied between 183 and $205 \mu \mathrm{M}$ (47 to 53\% saturation). Sediments were laminated and devoid of macrofauna, as since the end of the 1970s, the Kanholmsfjärd periodically suffers from low oxygen or anoxic conditions in the bottom water (Lännergren \& Eriksson 2000). Oxygen and temperature were measured in the water immediately above the sediment surface. Samples from the bottom water were taken for nutrient analyses. The sediment cores with ambient bottom water were kept cold $\left(6^{\circ} \mathrm{C}\right)$ immediately following sampling and during transport until the start of incubations at Kristineberg Marine Research Station, Göteborg University. In the laboratory, the cores were placed in a temperature-controlled $\left(6^{\circ} \mathrm{C}\right)$ laboratory and connected to a flow-through system $\left(20 \mathrm{ml} \mathrm{min}^{-1}\right)$. Continuous additions of $\mathrm{O}_{2}$-saturated seawater, directly supplied from a $30 \mathrm{~m}$ water depth just outside the research station, maintained the bottom-water well oxygenated. Appropriate salinity $(8 \%)$ for the sediment-water incubations was obtained by diluting the seawater with distilled water. The sediment cores were left open with a continuous replacement of bottom water for $45 \mathrm{~d}$. The overlying water volume was $0.8 \mathrm{l}$.

Individuals of Macoma balthica and Monoporeia affinis were collected in the Svärdsfjärd (east of Askö, Stockholm archipelago) in June 2000, while Marenzelleria viridis was collected in the Åland archipelago in July of the same year. All animals were collected by a grab sampler. Before starting the experiment in September 2000, animals were for 1.5 to 2 mo and adapted to experimental conditions in aquaria with natural sediment and air-saturated water of appropriate salinity (see above). The numbers of animals added to the various cores before starting the sediment-water incubations (see above) were within the upper range of natural densities (Table 1). In this study, we decided to normalise macrofaunal activities to animal density due to the different sizes and relations of the shell/body weight of the animals used. For example, a biomass of $M$. balthica appropriate for the experiment would correspond to unnaturally high densities $M$. affinis and $M$. viridis.
There were 4 replicate cores for each treatment, including the control (without animals) (Table 1). After animal additions, cores with sediment and water were again left to adjust for $29 \mathrm{~d}$. Solid-phase and porewater solute concentrations during similar incubations using coastal marine sediment from the Gullmar Fjord (western Sweden) confirm that the sediment/pore water system should have reached steady-state conditions after this time of acclimatisation (Skoog et al. 1996, S. Hulth unpubl. data). Following frequent visual inspections of cores, dead animals at the sediment surface were continuously replaced with an animal of similar size to keep the number of bioturbators constant. However, dead animals within the sediment were neither counted nor replaced, as this would have caused destruction of the biogeochemical structure of the surface sediment. The animals replaced during experiments were considered homologues to the ones initially added to the sediment cores.

After $29 \mathrm{~d}$ of acclimatisation, samples for measuring oxygen consumption, denitrification and benthic nutrient $\left(\mathrm{NH}_{4}{ }^{+}, \mathrm{NO}_{2}{ }^{-}+\mathrm{NO}_{3}{ }^{-}, \mathrm{Si}(\mathrm{OH})_{4}\right.$ and $\left.\mathrm{HPO}_{4}{ }^{2-}\right)$ fluxes were removed from the overlying water. Before sampling, the flow-through system was turned off and the cores were sealed with air-tight plexiglass lids. Lids included 2 polypropylene valves, 1 for sample removal and 1 for diluted sea water that simultaneously replaced water removed during sampling (Hulth 1995). A Teflon-coated magnetic stirring bar was attached to the top of the lid to mix the overlying water. For denitrification measurements, ${ }^{15} \mathrm{~N}$-labelled $\mathrm{K}-{ }^{15} \mathrm{NO}_{3}$ (Isotec) was added to the overlying water in all treatments to a final concentration of about $20 \mu \mathrm{M}$. The exact concentration was determined at the start of the flux measurements. The natural concentration of ${ }^{14} \mathrm{~N}$-nitrate in the overlying water after dilution was $5 \mu \mathrm{M}$. Before sampling, the isotope was left to penetrate into the sediment for 50 min under continuous stirring of the overlying water. Water samples (80 $\mathrm{ml}$ in total) for oxygen, nutrients $(\mathrm{n}=3$ ) and denitrification analyses were taken every third hour from the overlying water during an incubation period of $12 \mathrm{~h}$. The exact time of sam-

Table 1. Number of species and carbon content of the animals added to the cores of each treatment $(\mathrm{n}=4)$ prior to the sediment-water incubations. For comparison to in situ conditions, we have normalised the number of species to the surface area of the cores (ind. $\mathrm{m}^{-2}$ ). Indicated are shell-free dry weight (SFDW) and dry weight (DW) normalised to the surface area of the cores

\begin{tabular}{|lrrccc|}
\hline Treatments & Ind. core ${ }^{-1}$ & Ind. $\mathrm{m}^{-2}$ & $\begin{array}{c}\text { SFDW } \mathrm{m}^{-2} \\
(\mathrm{~g})\end{array}$ & $\begin{array}{c}\mathrm{DW} \mathrm{m}^{-2} \\
(\mathrm{~g})\end{array}$ & $\begin{array}{c}\text { Total C } \text { core }^{-1} \\
(\mathrm{~g})\end{array}$ \\
\hline Monoporeia affinis & 25 & 5000 & & 10 & 0.044 \\
Macoma balthica & 6 & 1200 & 36 & & 0.16 \\
Marenzelleria viridis & 25 & 5000 & & 16 & 0.066 \\
Control & 0 & 0 & 0 & 0 \\
\hline
\end{tabular}


pling was adjusted so that oxygen concentrations did not decrease by more than $20 \%$ from initial values (oxygen-saturated). Benthic flux rates were calculated from the initial linear change in solute concentration of the overlying water with time of incubation $(n=5)$. In addition, pre-incubations were performed to confirm that measured denitrification rates, originating from nitrate initially present in the pore water/overlying water (i.e. mainly ${ }^{28} \mathrm{~N}_{2}$ ), were independent of ${ }^{15} \mathrm{NO}_{3}{ }^{-}$ concentrations added to the overlying water. During pre-incubations, ${ }^{15} \mathrm{NO}_{3}{ }^{-}$was added to the overlying water of all cores (final concentrations 10, 40 and $80 \mu \mathrm{M}$ ). During the 2-point (start-end; total incubation time $3 \mathrm{~h}$ ) flux incubation, $30 \mathrm{ml}$ of overlying water was sampled each time. The overlying water was thoroughly and continuously replaced and the cores were left to re-equilibrate between incubations.

At the end of experiments, the overlying water was removed and the upper $10 \mathrm{~cm}$ of the sediment vertically sectioned at 0.25 or $0.5 \mathrm{~cm}$ intervals for pore water analyses. The samples were centrifuged and the pore water collected with a polypropylene syringe. The pore water was filtered through $0.45 \mu \mathrm{m}$ cellulose acetate filters before nutrient analyses. Solid sediment of control cores was stored frozen for later C and $\mathrm{N}$ analyses. In addition, animal survival and recovery were determined in connection with sediment sectioning.

Analyses and calculations. Oxygen concentrations during the flux incubations were determined using Winkler titrations, while oxygen during the field sampling was measured by a Clark-type macroelectrode. The macrosensor was calibrated at 0 and $100 \%$ oxygen saturation. Nutrients $\left(\mathrm{NH}_{4}{ }^{+}, \Sigma \mathrm{NO}_{2}{ }^{-}+\mathrm{NO}_{3}{ }^{-}, \mathrm{Si}(\mathrm{OH})_{4}\right.$ and $\mathrm{HPO}_{4}{ }^{2-}$ ) in the overlying water and pore water were analysed using an auto-analyser (TRAACS 800) according to standard colorimetric methods (Strickland $\&$ Parsons 1972). The limit of detection was estimated from the variation in recorded signal (3 $\times \mathrm{SD})$ in the pore water, where nitrate was considered to be depleted $(>4 \mathrm{~cm}$, $\mathrm{n}=8$ ), or from variations in the baseline drift during nutrient analysis (ammonium, phosphate and silicate). Samples for denitrification rates were sent to the National Environmental Research Institute in Silkeborg, Denmark, and analysed according to the nitrogen isotope pairing technique (Steingruber et al. 2001, Risgaard-Petersen et al. 2003). Organic and inorganic carbon, and organic nitrogen in the solid phase of the sediment were measured by a Fisons Instruments Na $1500 \mathrm{NC}$ elemental analyser.
All measurements are reported as mean \pm SE. Differences between control and inhabited sediments were tested using a 1-way analysis of variance (ANOVA) with treatments as fixed factors. Homogeneity of variances was checked using Cochran's test and when found to be heterogeneous, the data were logtransformed (Underwood 1997). In cases of significance of the ANOVA test, pair-ways comparisons of the means were made using Fisher's PLSD test. Differences were accepted as significant at $\mathrm{p}<0.05$.

\section{RESULTS}

\section{Survival and distribution of macrofauna}

Mortality of Monopereia affinis (found at the sediment surface) decreased with time during the experiment (Fig. 2). After $19 \mathrm{~d}$, there was only 1 dead $M$. affinis found in all 4 replicates, as compared to a total of 25 animals $3 \mathrm{~d}$ after starting the incubations. $M$. affinis was mainly found in the upper $1 \mathrm{~cm}$ (Fig. 3), with a recovery yield from 20 to $80 \%$. Between 73 and $100 \%$ of recovered animals were alive at the end of the experiment. In cores with $M$. affinis, the top $1 \mathrm{~cm}$ below the sediment-water interface had a light brownish colour with a 'fluffy' texture at termination.

All individuals of Macoma balthica were found at retrieval, of which 67 to $100 \%$ were alive at the end of the experiment. However, there was no indication of decreasing mortality with incubation time (Fig. 2). Of the $24 \mathrm{M}$. balthica initially added, 24 were replaced. From visual inspections, it was concluded that activities of $M$. balthica formed groves and holes of about the same size as the animal $(1.5 \mathrm{~cm})$ to a sediment depth of about $3.5 \mathrm{~cm}$ (Fig. 3).

Initially, Marenzelleria viridis dug into the sediment and were found down to about $7.5 \mathrm{~cm}$ (Fig. 3). How-

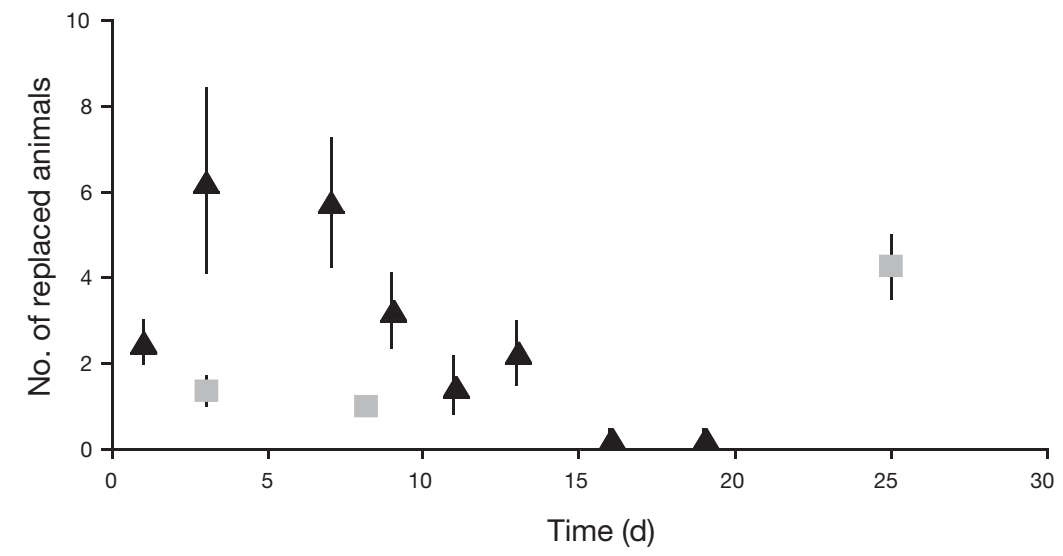

Fig. 2. Monoporeia affinis and Macoma balthica. Number of replaced M. affinis $(\boldsymbol{\Delta})$ and $M$. balthica ( $\square$ ) during an adaptation period of $29 \mathrm{~d}$. Error bars represent $\mathrm{SE}(\mathrm{n}=4)$ 


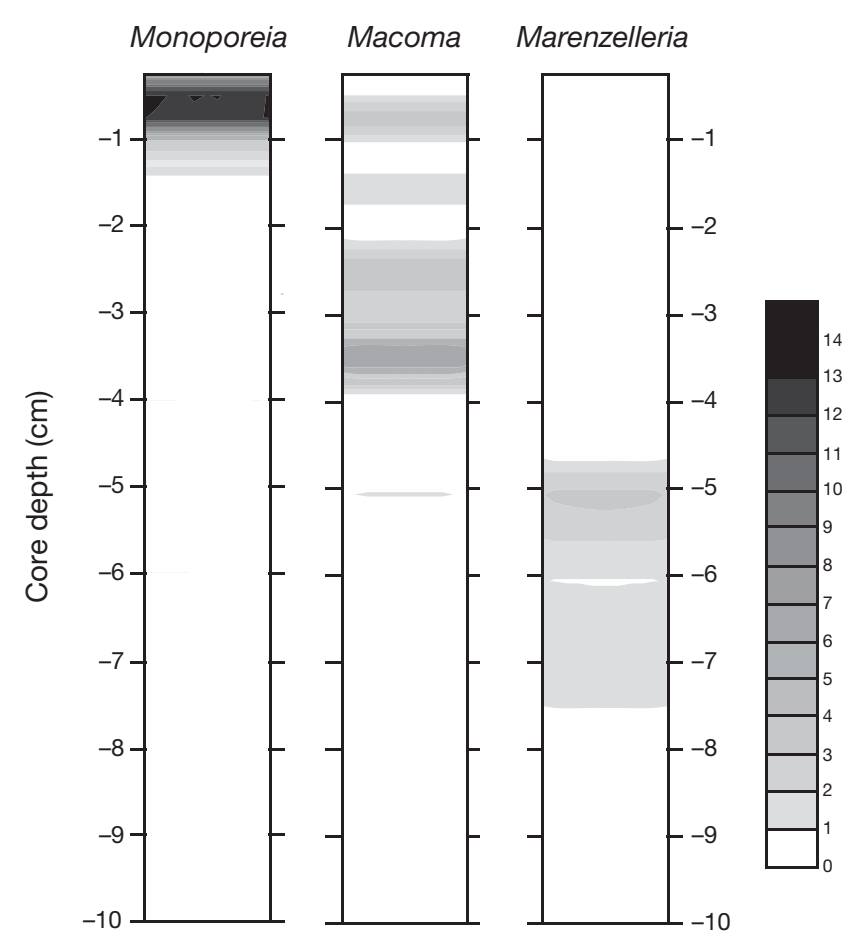

Fig. 3. Monoporeia affinis, Macoma balthica and Marenzelleria affinis. Distribution of $M$. affinis, $M$. balthica and $M$. affinis in sediment cores after an adaption period of $29 \mathrm{~d}$. The greyscale illustrates the number of animals. Data are interpolated according to Kringing using the program Surfer

ever, recovery of $M$. viridis was only $8 \%$ (62\% alive). There were no fecal pellets found on the sediment surface; i.e. feeding and digging activity in the $M$. viridis cores seemed to stop after the initial period. On 1 occasion only (19 d after animal addition) 4 dead $M$. viridis were found at the sediment surface in 1 core and could, thus, be replaced.

The carbon content of the animals added was 0.044, 0.16 and $0.66 \mathrm{~g} \mathrm{C} \mathrm{Core}^{-1}$ for Monopereia affinis, Macoma balthica and Marenzelleria viridis, respectively. Assuming a depth of residence for these animals of 1, 3.5 , and $7.5 \mathrm{~cm}$, respectively and a mean $\mathrm{C}$ content in this layer of $7 \%$ (see next subsection), the $\mathrm{C}$ contribution from the added animals was less than $5 \%$ of the total $\mathrm{C}$ content in the solid phase of this bioturbated zone of the sediment (Table 1). Although $\mathrm{C}$ in animal tissues is more labile and easily available to microbes in the anoxic environment than organic $\mathrm{C}$ initially present in the sediment, input of carbon substrate by dead animals (found or not recovered) was assumed not to have influenced overall microbial activity and the availability of oxidants/reductants in the sediment. However, a decreased macrofaunal activity due to animal mortality may have influenced the biological induced transport of solutes.

\section{Sediment characteristics and organic matter mineralisation}

$\mathrm{C}$ and $\mathrm{N}$ content in the solid phase of the upper $10 \mathrm{~cm}$ sediment layer for the control cores decreased slightly with depth, the organic $\mathrm{C}$ content from 7.0 to $6.2 \%$, and total $\mathrm{N}$ from 0.86 to $0.75 \%$. The $\mathrm{C}: \mathrm{N}$ ratio was thus rather constant with depth and slightly higher (between 8.4 and 8.7) than predicted from the Redfield relation ( $\mathrm{C}: \mathrm{N}=106: 16)$. Solid-phase inorganic carbon was insignificant compared to organic carbon $(<5 \%$ of total C).

\section{Pore-water distributions}

Overall, concentrations of $\mathrm{NH}_{4}{ }^{+}, \mathrm{HPO}_{4}{ }^{2-}$ and $\mathrm{Si}(\mathrm{OH})_{4}$ were higher in the sediment than in the overlying water, indicating nutrient mobilisation to the pore water during benthic mineralisation of organic material. No significant differences were found in porewater distribution patterns between macrofauna treatments and the control, although there were indications of lower silicate and higher ammonium, nitrate and phosphate concentrations in the top few centimeters of the Macoma balthica cores than for the other cores (Fig. 4). Phosphate concentrations were low down to a sediment depth of $2 \mathrm{~cm}$ in the Monoporeia affinis cores, 5 to $10 \mu \mathrm{M}$ compared to $>20 \mu \mathrm{M}$ for the control (Fig. 4A). Nitrate concentrations were low in all treatments $(<0.5 \mu \mathrm{M})$ and nitrate was not found below a sediment depth of $\sim 2 \mathrm{~cm}$ (Fig. 4D).

\section{Benthic oxygen, silicate and phosphorous fluxes}

Representative examples of the oxygen and nutrient response in the overlying water during the sedimentwater incubations are illustrated in Fig. 5. Measured benthic fluxes of $\mathrm{O}_{2}, \mathrm{Si}(\mathrm{OH})_{4}$ and $\mathrm{HPO}_{4}{ }^{2-}$ ranged from 13 to $46,1.2$ to 3.3 and 0.024 to $0.39 \mathrm{mmol} \mathrm{m}^{2} \mathrm{~d}^{-1}$, respectively (Figs. $6 \& 7$ ). Treatments with Monopereia affinis and Macoma balthica showed significantly (Fisher's PLSD: $p<0.01$ and $p<0.05$ ) higher rates of oxygen consumption $\left(27 \pm 4.8\right.$ and $34 \pm 9.4 \mathrm{mmol} \mathrm{m}^{2}$ $\left.\mathrm{d}^{-1}\right)$ compared to the control $\left(16 \pm 3.3 \mathrm{mmol} \mathrm{m}^{2} \mathrm{~d}^{-1}\right)$ (Fig. 6). Enhanced oxygen fluxes were not, however, statistically confirmed for the Marenzelleria viridis cores. Although statistically not confirmed, there were indications of enhanced silicate fluxes in treatments with macrofauna compared to the control, close to significance for $M$. affinis and M. balthica (Fisher's PLSD: $\mathrm{p}=0.067$ and $\mathrm{p}=0.052$ ) (Fig. 7A). A relatively large variation between $M$. balthica cores was found for benthic phosphate fluxes (Fig. 7B); significantly larger 


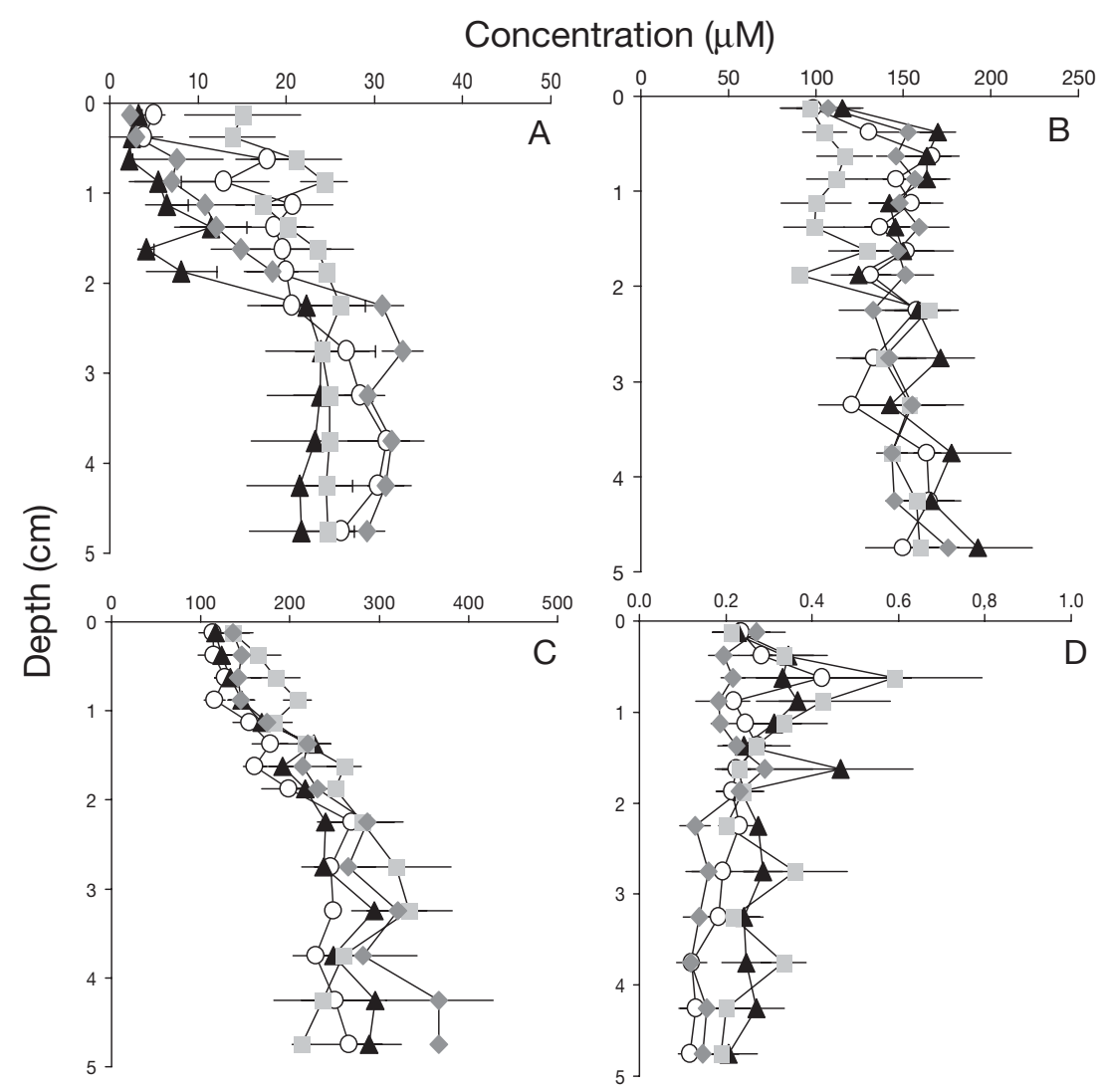

Fig. 4. Monoporeia affinis, Macoma balthica and Marenzelleria affinis. (A) Phosphate; (B) silicate; (C) ammonium; (D) nitrate pore-water distributions after termination of the sediment-water incubations (29 d) for the control (O), M. affinis $(\boldsymbol{\Delta}), M$. balthica $(\square)$ and $M$. viridis $(\diamond)$ cores. Error bars indicate SE $(\mathrm{n}=4)$

\section{Nitrogen mineralisation and benthic $\mathrm{N}$ fluxes}

There were indications of a pronounced release of $\mathrm{NH}_{4}{ }^{+}$from the sediment to the overlying water in cores with macrofauna; this was significant for the Macoma balthica (Fisher's PLSD: $p<0.001$ ) cores (Figs. 8 \& 9, Table 2). Effects from additions of macrofauna were also observed for benthic $\mathrm{NO}_{3}{ }^{-}$fluxes (Fig. 8). A negative $\mathrm{NO}_{3}{ }^{-}$flux, i.e. a transport of $\mathrm{NO}_{3}{ }^{-}$from the overlying water to the sediment, indicates an additional pathway other than coupled nitrification/denitrification in the sediment of importance for denitrification (Table 2). Although only significant for $M$. balthica (Fisher's PLSD: $\mathrm{p}<0.01)$, there was a tendency for the presence of macrofauna to stimulate $\mathrm{NO}_{3}{ }^{-}$consumption in the sediment (Table 2).

Denitrification rates were independent of the added ${ }^{15} \mathrm{~N}$-isotope concentrations $(10,40$ and $80 \mu \mathrm{M})$ as determined in preincubations. Hence, additions of ${ }^{15} \mathrm{NO}_{3}{ }^{-}$ to a final concentration of $20 \mu \mathrm{M}$ did not affect denitrification rates (i.e. production of ${ }^{28} \mathrm{~N}_{2}$ ) compared to the initial $5 \mu \mathrm{M}$ in the overlying water.

Overall, measured denitrification rates (Fisher's PLSD: p < 0.05) compared to the control. In $M$. affinis and $M$. viridis cores, phosphate fluxes were relatively low, about the same size as those of the control. were significantly ( $\sim 2$ orders of magnitude) lower than nitrate fluxes into the sediment. Measured total rates of denitrification indicated higher rates in treatments with Monopereia affinis (43 $\left.\pm 19 \mu \mathrm{mol} \mathrm{N}_{2} \mathrm{~m}^{-2} \mathrm{~d}^{-1}\right)$ compared
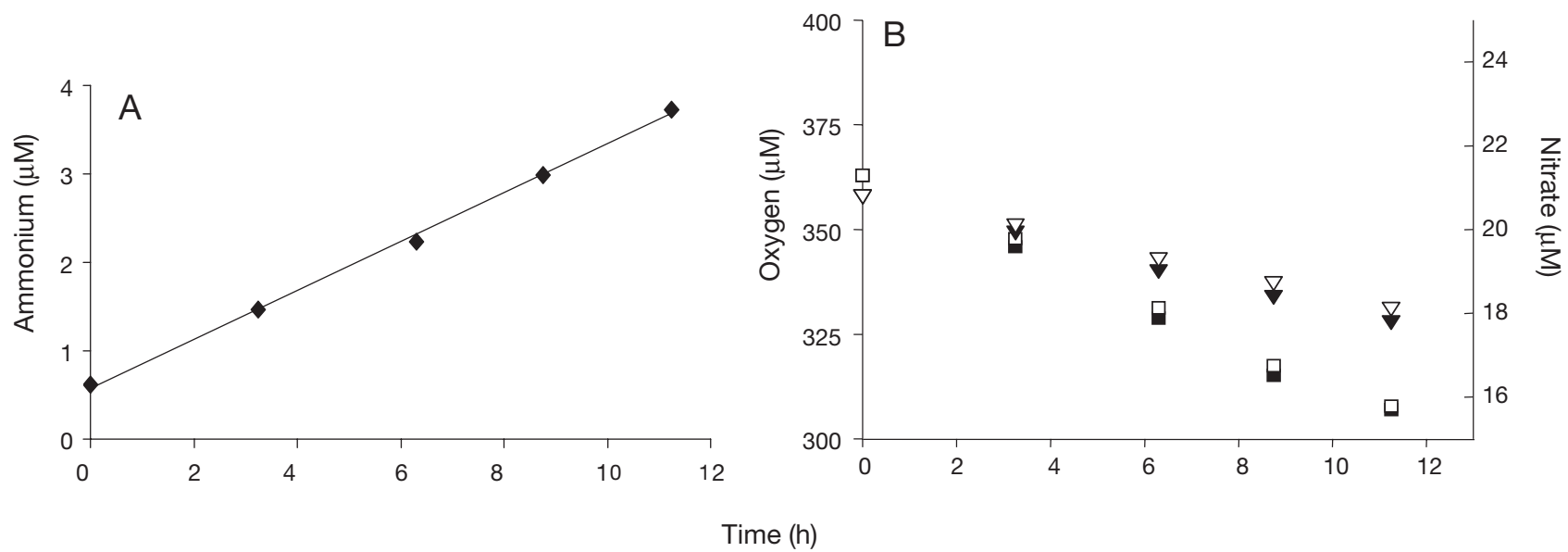

Fig. 5. Representative examples on the evolution of (A) ammonium and (B) oxygen ( $\mathbf{\square})$ and nitrate ( $\mathbf{\nabla})$ in the overlying water during the sediment-water incubations. Open symbols indicate actual concentrations in the overlying water, while filled symbols denote concentrations corrected for the incoming replacement water during sampling 


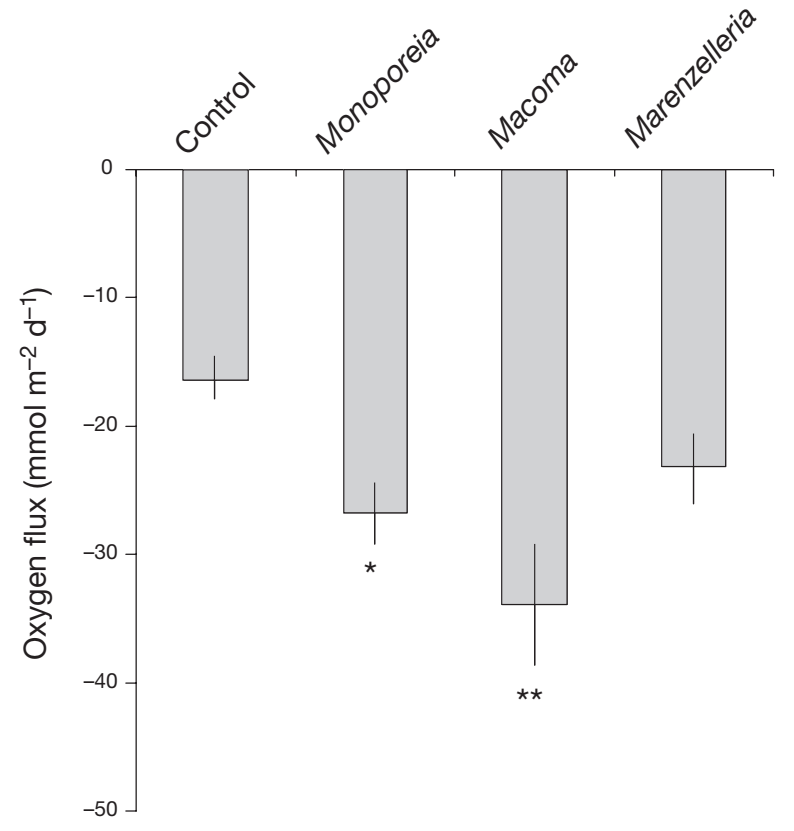

Fig. 6. Monoporeia affinis, Macoma balthica and Marenzelleria affinis. Oxygen consumption in the control cores and the cores treated with $M$. affinis, $M$. balthica and $M$. affinis. Error bars indicate SE $(\mathrm{n}=4)$. Fisher's PLSD: ${ }^{*} \mathrm{p}<0.05,{ }^{*} \mathrm{p}<0.01$
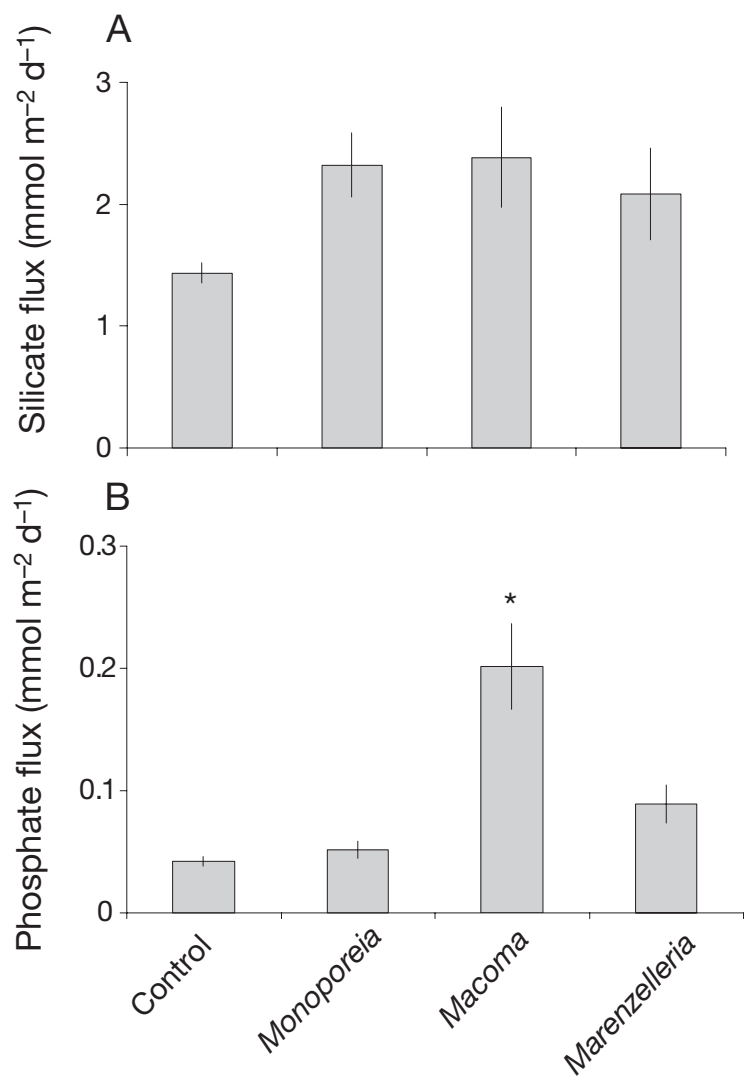

Fig. 7. Monoporeia affinis, Macoma balthica and Marenzelleria affinis. Benthic fluxes of (A) silicate and (B) phosphate in the control cores and the $M$. affinis, $M$. balthica and $M$. affinis cores. Error bars indicate SE $(n=4)$. Fisher's PLSD: ${ }^{*} \mathrm{p}<0.05$

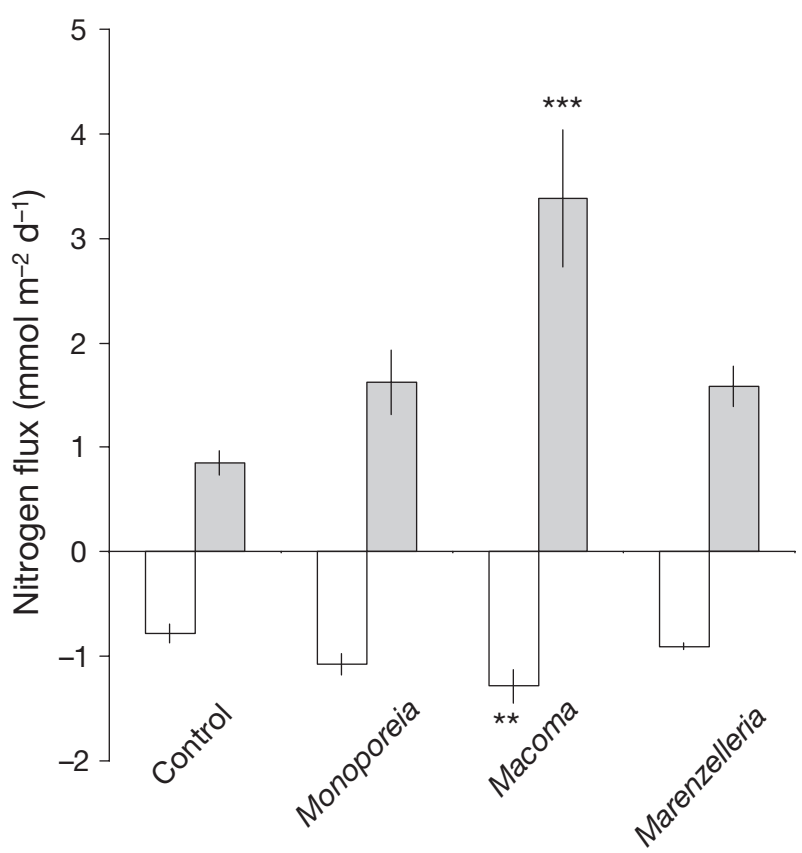

Fig. 8. Monoporeia affinis, Macoma balthica and Marenzelleria affinis. Ammonium and nitrate fluxes in the control cores and cores treated with $M$. affinis, $M$. balthica and $M$. affinis. Filled symbols denote ammonium fluxes and open symbols denote nitrate fluxes. Error bars indicate SE $(\mathrm{n}=4)$. Fisher's PLSD: ${ }^{* *} \mathrm{p}<0.01 ; * * * \mathrm{p}<0.001$

to the control; however, these rates were not significant $\left(26 \pm 12 \mu \mathrm{mol} \mathrm{N} \mathrm{m}^{-2} \mathrm{~d}^{-1}\right.$; Fig. 10, Table 2). This increased rate was caused by a significantly (Fisher's PLSD: $p<$ 0.05 ) stimulated supply of nitrate from the overlying water $\left(D_{w}\right)$, while coupled nitrification/denitrification $\left(D_{n}\right)$ was similar to the control. Average $\mathrm{D}_{\mathrm{w}}$ represented about $80 \%$ of total denitrification in the $M$. affinis cores (Fig. 10). In the other treatments, measured $\mathrm{D}_{\mathrm{w}}$ was similar to the control $\left(\sim 10 \mu \mathrm{mol} \mathrm{N} \mathrm{m}^{-2} \mathrm{~d}^{-1}\right)$. Coupled nitrification/denitrification $\left(D_{n}\right)$ was, however, slightly higher in the control cores $\left(16 \mu \mathrm{mol} \mathrm{N} \mathrm{N}_{2} \mathrm{~m}^{-2} \mathrm{~d}^{-1}\right)$ than in the macrofaunal treatments (5 to $9 \mu \mathrm{mol} \mathrm{N} \mathrm{N}_{2} \mathrm{~m}^{-2} \mathrm{~d}^{-1}$ ).

Overall, variability between replicate cores containing macrofauna was larger compared to the control replicates (Figs. 6-10). For example, relative SE of the $\mathrm{NH}_{4}{ }^{+}$-fluxes in the control cores was $23 \%$, but $39 \%$ in the Monopereia affinis cores and $38 \%$ in the Macoma balthica cores, respectively.

\section{DISCUSSION}

\section{Survival and distribution of fauna}

Survival of Monopereia affinis increased with time of incubation and reworking of the sediment, probably due to irrigation and the subsequent oxidation of the 


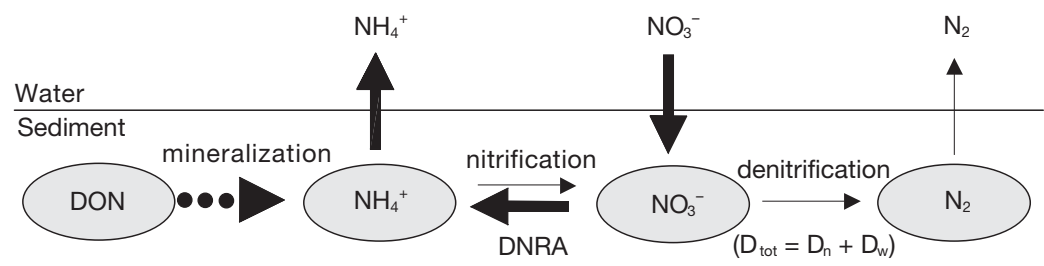

Fig. 9. Benthic flux rates of ammonium and nitrate, rates of denitrification of nitrate supplied from the overlying water $\left(D_{w}\right)$, from coupled nitrification/denitrification $\left(D_{n}\right)$ and total denitrification $\left(D_{\text {tot }}\right)$. The balance between nitrification and dissimilatory nitrate reduction to ammonium (DNRA) was estimated from the nitrate flux and total denitrification. Mass balance calculations of net nitrogen mineralisation $\left(\mathrm{N}_{\min }=\right.$ ammonium flux + nitrate flux + total denitrification) indicated that a major fraction of nitrate supplied from the overlying water was reduced to ammonium and contributed to the observed ammonium flux from the sediment to the overlying water. A negative flux indicates a transport from the overlying water into the sediment

surrounding sediment, and removal of toxic metabolites (e.g. hydrogen sulphide) in the pore water. Field observations have shown that the amphipods $M$. affinis and Pontoporeia femorata are the first benthic species to colonise a sediment area following improved oxygen conditions in the bottom water (Laine et al. 1997). In a laboratory experiment, $M$. affinis (8000 ind. $\mathrm{m}^{-2}$ ) was able to oxidise the upper $8 \mathrm{~mm}$ of a sulphide-rich sediment in less than $2 \mathrm{wk}$ (Modig \& Ólafsson 2001). Oxidation of labile sulphides was found to be directly related to macrofaunal density. Quite contradictory to these observations, $M$. affinis has been classified as a species intolerant to reduced environments in physiological studies and not capable of detoxifying reduced compounds such as hydrogen sulphide (Hagerman et al. 1997, Sandberg-Kilpi et al. 1999). Modig \& Ólafsson (2001) suggested that this discrepancy between observations could be attributed to the formation of sulphide-free pockets in the sediment by irrigation of oxygen-rich overlying water into the burrows of $M$. affinis.

Compared to Monopereia affinis, Macoma balthica is a semi-mobile detritivore assumed mainly to influence the region close to the sediment-water interface through facultative suspension- and deposit feeding (Mortimer et al. 1999). M. balthica digs into the sediment using its foot and occasionally, often associated with food limitation or oxygen stress, moves vertically in the sediment (Trueman \& Ansell 1969). Although there is no direct ventilation of the burrow, oxygenated zones have been observed directly adjacent to the bivalves (Reise 1983). Reise (1983) suggested that the exhalant siphone of the bivalve may not extend to the sediment surface. Instead, the bivalve provides its vicinity with oxygenated water via the release of respiratory water through the exhalent siphone, a way to prevent hydrogen sulphide of the sediment from direct contact with the bivalve. However, oxygen eventually brought by the bivalve into the highly reducing sediment of this study was probably readily consumed during oxidation of reduced metabolites in the surrounding sediment. $M$. balthica is known to be rather tolerant of hydrogen sulphide (Jahn \& Theede 1997, Jahn et al. 1997). However, a relatively large number of dead individuals were found in this experiment, and there was no indication of decreasing mortality of the animal with incubation time. According to Jahn \& Theede (1997), populations of $M$. balthica show different degrees of sulphide tolerance in relation to sulphide contamination of habitats. Specimens from areas with high sulphide concentrations showed higher survival capacities during sulphide exposure in the laboratory than specimens from less contaminated areas (Jahn \& Theede 1997). Specimens of M. balthica used in this experiment were collected in an area with well-oxygenated bottom water, and were adjusted to an oxygen-saturated environment before experiments. It is therefore possible that specimens used during the sediment-water incubations in this study were not pre-adapted to the sulphidic conditions of the laminated Baltic Sea sediments.

Survival of Marenzelleria viridis in the experiment was low. Other laboratory studies have demonstrated that $M$. viridis has the capacity to efficiently use oxygen during hypoxia, but only exhibits a moderate resistance to anoxia compared to other polychaetes (Schiedek 1997). Due to the low survival rate of

Table 2. Values (mean $\pm \mathrm{SE}_{i} \mathrm{n}=4$ ) for the processes shown in Fig. 9

\begin{tabular}{|c|c|c|c|c|c|c|c|}
\hline Treatments & $\begin{array}{l}\mathrm{NH}_{4}^{+} \text {flux } \\
(\mathrm{mmol} \\
\left.\mathrm{m}^{-2} \mathrm{~d}^{-1}\right)\end{array}$ & $\begin{array}{l}\mathrm{NO}_{3}^{-} \text {flux } \\
(\mathrm{mmol} \\
\left.\mathrm{m}^{-2} \mathrm{~d}^{-1}\right)\end{array}$ & $\begin{array}{c}\text { Nitr.-DNRA } \\
\left(\mathrm{mmol}^{-2} \mathrm{~d}^{-1}\right)\end{array}$ & $\begin{array}{c}\mathrm{N}_{\min } \\
\left(\mathrm{mmol}^{-2} \mathrm{~d}^{-1}\right)\end{array}$ & $\begin{array}{c}D_{n} \\
(\mu m o l \\
\left.m^{-2} d^{-1}\right)\end{array}$ & $\begin{array}{c}\mathrm{D}_{\mathrm{w}} \\
(\mu \mathrm{mol} \\
\left.\mathrm{m}^{-2} \mathrm{~d}^{-1}\right)\end{array}$ & $\begin{array}{c}\mathrm{D}_{\text {tot }} \\
(\mu \mathrm{mol} \\
\left.\mathrm{m}^{-2} \mathrm{~d}^{-1}\right)\end{array}$ \\
\hline Monoporeia affinis & $1.6 \pm 0.31$ & $-1.1 \pm 0.10$ & $-1.1 \pm 0.09$ & $0.77 \pm 0.27$ & $7.8 \pm 1.6$ & $35 \pm 10$ & $43 \pm 9.9$ \\
\hline Macoma balthica & $3.4 \pm 0.66$ & $-1.3 \pm 0.16$ & $-1.4 \pm 0.06$ & $2.3 \pm 0.45$ & $5.9 \pm 2.1$ & $11 \pm 3.7$ & $17 \pm 2.3$ \\
\hline Marenzelleria viridis & $1.6 \pm 0.19$ & $-0.91 \pm 0.03$ & $-0.89 \pm 0.035$ & $0.69 \pm 0.16$ & $7.4 \pm 2.3$ & $8.7 \pm 2.0$ & $16 \pm 2.1$ \\
\hline Control & $0.86 \pm 0.11$ & $-0.78 \pm 0.09$ & $-0.83 \pm 0.07$ & $0.055 \pm 0.09$ & $15 \pm 4.0$ & $9.9 \pm 3.4$ & $25 \pm 6.7$ \\
\hline
\end{tabular}




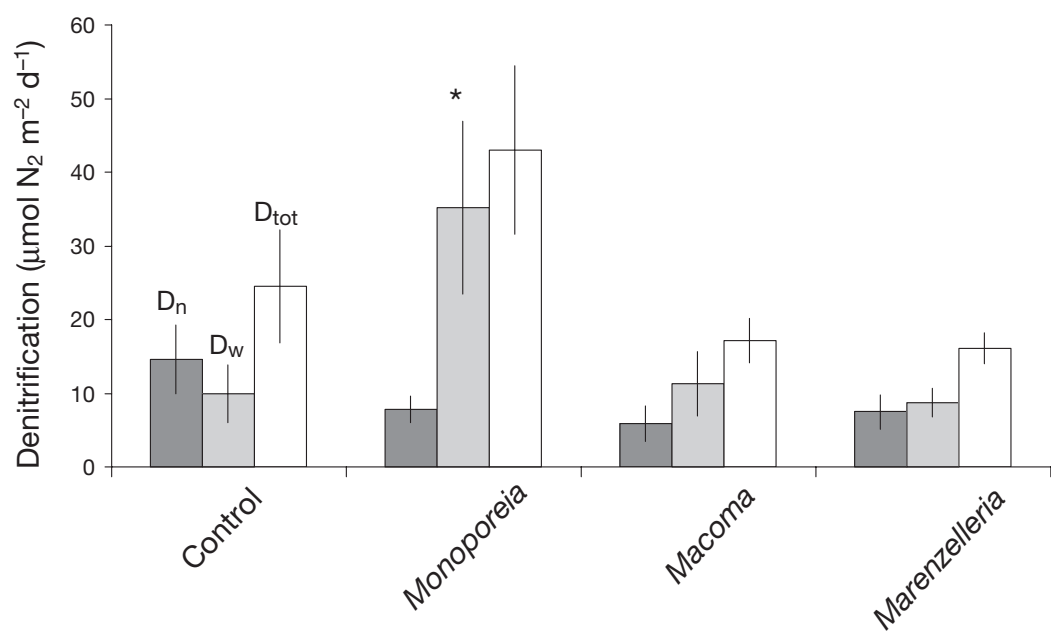

Fig. 10. Monoporeia affinis, Macoma balthica and Marenzelleria affinis. Coupled nitrification/denitrification ( $\mathrm{D}_{\mathrm{n} i}$ dark shaded bars), denitrification from nitrate supplied from the overlying water $\left(\mathrm{D}_{\mathrm{w}}\right.$ light bars) and total denitrification ( $\mathrm{D}_{\text {toti }}$ open bars) as measured by the isotope pairing technique (Steingruber et al. 2001, Risgaard-Petersen et al. 2003). Rates are indicated for the control cores and cores with $M$. affinis, $M$. balthica and $M$. affinis. Error bars indicate SE $(\mathrm{n}=4)$. Fisher's PLSD; * $\mathrm{p}<0.05$

M. viridis, the degree of bioturbation and bioirrigation in cores populated by $M$. viridis was most likely low. The highly porous sediment may have prevented $M$. viridis from constructing intact burrows that extended deep into the sediment. Unconsolidated, and therefore unstable, constructions may have collapsed during the incubations and prevented further ventilation and oxygenation of the sediment.

The comparably shallow burrowing depth found for most individuals in this experiment (Macoma balthica $3.5 \mathrm{~cm}$, Monopereia affinis $1.25 \mathrm{~cm}$ and Marenzelleria viridis $7.5 \mathrm{~cm}$; Fig. 3) probably reflected the reducing conditions of the laminated Baltic Sea sediment. It is known that benthic fauna generally emerge closer to the sediment surface during decreased oxygen conditions (Pearson \& Rosenberg 1978, Baden et al. 1990). However, the tendency to migrate to the sediment surface prior to death seemed different among species. Consequently, the possibility to replace dead animals differed among species, which may have contributed or be the actual cause of the different survival rates found for the 3 species.

\section{Sediment biogeochemistry}

Pore water distributions and benthic fluxes

Overall, patterns of solute distribution in the pore water were in accordance with those normally observed in highly anoxic sediments (Fig. 4). For example, despite oxygen-saturated overlying bottom wa- ters, nitrate concentrations in the pore water were low and the zone of net nitrate production restricted to less than $10 \mathrm{~mm}$ below the sediment-water interface. Observations thus confirmed that the experimental set-up and laboratory conditions used during the experiments were appropriate and simulated a recolonisation event under highly anoxic conditions in the surface sediment.

Through ventilation and construction activities by the mobile detritivore Monoporeia affinis, the uppermost centimeters of the initially black, laminated sediment turned light brownish with a fluffy sediment texture during the acclimatisation period of $29 \mathrm{~d}$. This indicated a higher degree of oxygenation through direct macrofaunal irrigation of overlying water into the surface sediment. Below this surface layer, the sediment was again black and resembled the sediment initially found at sampling. From visual inspections, Macoma balthica and Marenzelleria viridis seemed not to have oxygenated the surface sediment as efficiently as $M$. affinis. This may be, at least to some extent, explained by the lower survival rates (or possibility of replacing dead animals) found for these species, especially for $M$. viridis. The low survival rate found for $M$. viridis can most likely also explain the generally low nutrient fluxes in these cores.

A decreased phosphate concentration in the pore water during oxygenation of the sediment and subsequent formation of $\mathrm{Fe}$ - and $\mathrm{Mn}$-oxides may be directly associated with bioturbation and macrofaunal reworking activities (Mortimer et al. 1999, Tuominen et al. 1999). In this study, phosphate concentrations in the upper $2 \mathrm{~cm}$ of the Monoporeia affinis cores seemed lower than in the control cores, but with a large within-treatment variation (Fig. 4A). In spite of large variation between replicate cores, there was a tendency for an enhanced flux of phosphate from the sediment in the Macoma balthica cores compared to the control (Fig. 7B). Phosphate fluxes in the M. affinis cores were similar to the control, supporting observations of phosphate immobilisation in the first few centimeters of the sediment. Mobilisation of phosphate to the pore water and subsequent transport across the sediment-water interface is often a consequence of a redox transition towards more reducing conditions in the overlying water, or an enhanced supply of reductants to the surface sediment (Sundby et al. 1986). Additionally, pore water phosphate may be directly transferred to the overlying water by biologically 
induced advection of the pore water. In our study, an increased phosphate flux from the sediment (only significant for $M$. balthica, Fisher's PLSD: $p$ < 0.05) was most likely due to the combined effects of these factors, possibly supported by faunal excretion of organic/inorganic $\mathrm{P}$ fractions.

Some macronutrients (e.g. ammonium, nitrate and phosphate) have strong redox-dependent distribution patterns in the ocean. Silicate, however, is generally considered a conservative nutrient, and does not normally participate in biogeochemical reactions other than the formation and dissolution of biogenic opal $\left(\mathrm{SiO}_{2}\right)$. Pore water distributions and benthic fluxes of silicate are therefore sometimes used as an indication of solute transport enhancement caused by macrofaunal irrigation in sediments (Boudreau 1997, Mortimer et al. 1999, Aller 2001). The difference between a diffusive transport along concentration gradients in the top sediment layer, and benthic fluxes measured during the sediment-water incubation, is mainly attributed to particle displacement and water irrigation induced by benthic macrofauna, and the multidimensional surface extension created by animal activities. Accordingly, there were indications of enhanced fluxes of silicate (not statistically confirmed) from the sediment to the overlying water in the Monoporeia affinis (61\%) and Macoma balthica (66\%) cores compared to the control. In Marenzelleria viridis cores, the average increase was lower (45\%). This stimulated solute transport of a conservative element indicated that macrofaunal irrigation activities may also have affected benthic fluxes for other solutes in our study. Concentrations of silicate in the pore water were similar between treatments and the control, although slightly lower in sediments populated by $M$. balthica. Oxygen is the primary oxidant in aquatic sediment systems and is often rapidly consumed during heterotropic and autotrophic microbial respiration, as well as by macrofaunal respiration (Froelich et al. 1979, Berner 1980, Aller 2001). Depending on general sediment characteristics and physical and biological processes affecting the surface sediment layer, the relative importance of oxygen reduction pathways may be adjusted. For sediments that receive a pronounced amount of organic material, oxygen is only available in a narrow layer just below the sediment-water interface (often $<1 \mathrm{~mm}$ ). Reoxidation of reduced species other than $\mathrm{C}$ and $\mathrm{N}$ (e.g. $\mathrm{Fe}(\mathrm{II}), \mathrm{Mn}(\mathrm{II})$ and $\mathrm{HS}^{-}$) often constitutes important pathways of oxygen reduction in such sediments (Jørgensen 1977, Thamdrup 2000). Due to the high organic carbon content (6 to $7 \%$ ) in the Baltic Sea sediments of this study, the availability of reduced compounds is high; therefore, in addition to the oxidation of reduced $\mathrm{C}$, oxygen consumption most likely proceeded to a large extent through oxidation of reduced $\mathrm{Fe}, \mathrm{Mn}$ and $\mathrm{S}$ species. Oxygen consumption was significantly higher in treatments with $M$. affinis and $M$. balthica compared to the control. A stimulated benthic oxygen consumption attributed to bioturbating fauna has been reported for fresh water (Svensson \& Leonardson 1996) as well as for marine environments (Aller 2001, Gilbert et al. 2003).

Nitrogen mineralisation and benthic $\mathrm{N}$ fluxes

Ammonium is often the primary $\mathrm{N}$-containing metabolic product of heterotrophic metabolism. Ammonium and dissolved organic $\mathrm{N}$ (DON) are also excretory products of zooplankton and protozoans, and DON released by excretion or cell lysis has the potential to be further mineralised to $\mathrm{NH}_{4}^{+}$(Blackburn 1983). Excretion of ammonium or low-molecular weight DON (e.g. urea) may also be significant from benthic macrofauna. For example, experiments using another bivalve (Theora lata) revealed that ammonium excretion enhanced ammonium fluxes to a larger extent than did bioturbation activities (Magni et al. 2000). Correlations between $\mathrm{NH}_{4}{ }^{+}$efflux and density of Macoma balthica have been observed (Mortimer et al. 1999). The $\mathrm{NH}_{4}{ }^{+}$concentration in the pore water of $M$. balthica cores in this study was slightly higher compared to the control and the other treatments (Fig. 4C). Furthermore, activities by $M$. balthica enhanced the benthic $\mathrm{NH}_{4}{ }^{+}$flux by almost a factor of 4 compared to the control (Fig. 8; Table 2). There were also indications of increased ammonium fluxes in the Monoporeia affinis cores; however, these were not statistically confirmed (Fig. 8; Table 2). Tuominen et al. (1999) calculated ammonium excretion by $M$. affinis to be 5 to $10 \%$ of the total ammonium flux, supporting the idea of less ammonium being mobilised during macrofaunal excretion in the $M$. affinis cores compared to the M. balthica cores.

The relatively large fluxes of nitrate into the sediment obtained during the sediment-water incubations indicated significant benthic denitrification for all treatments (Fig. 8). However, rates of total denitrification were in general significantly lower than indicated from the nitrate flux into the sediment. Measured denitrification rates demonstrated that denitrification using nitrate supplied from the overlying water $\left(D_{w}\right)$ was more important than coupled nitrification/denitrification $\left(D_{n}\right)$ for cores with Monoporeia affinis (Fig. 10). In these cores, more than $80 \%$ of total denitrification proceeded through nitrate supplied from the overlying water. Increased importance of $\mathrm{D}_{\mathrm{w}}$ for total denitrification in manipulated cores with $M$. affinis is associated with a direct supply of $\mathrm{NO}_{3}{ }^{-}$from the overlying water 
to the sediment interior by animal activities. In similar experiments using Mya arenaria, Cerastoderma sp. (Bivalvia) and Nereis sp. (Polychaeta), the bivalves stimulated $\mathrm{D}_{\mathrm{n}}$ more than $\mathrm{D}_{\mathrm{w}}$, while Nereis sp. preferentially stimulated $D_{\mathrm{w}}$ (Pelegrí \& Blackburn 1995). The polychaetes stimulated $D_{w}$ and $D_{n}$ rates by about 2 times more than the bivalves, an observation suggested to be attributed to the different irrigation mechanisms used by the bivalves and the polychaetes, respectively. However, in sediments from the Gulf of Finland, Tuominen et al. (1999) observed that $D_{n}$ represented 64 to $84 \%$ of total denitrification in sediments with $M$. affinis ( 1500 ind. $\left.\mathrm{m}^{-2}\right) . \mathrm{NO}_{3}{ }^{-}$concentration in the pore water was about $5 \mu \mathrm{M}$, supporting the potential for nitrate mobilisation and coupled nitrification/ denitrification in sediments of the Gulf of Finland. In our experiment, using highly reducing sediment from the Baltic Sea, $\mathrm{NO}_{3}{ }^{-}$concentrations in the pore water were significantly lower, often $<0.5 \mu \mathrm{M}$. The relative partitioning of $D_{n}$ and $D_{w}$ to total denitrification largely depends on the overlying water concentration of nitrate, and the availability of oxidants/reductants in the sediment (Henriksen \& Kemp 1988, Nielsen 1992). Highly reducing sediments underlying bottom waters with high nitrate concentrations are likely to stimulate transport of nitrate from the overlying water to the sediment, promoting $\mathrm{D}_{\mathrm{w}}$.

For the manipulated and control cores, the benthic nitrate fluxes into the sediment were significantly larger than measured total denitrification $\left(D_{w}+D_{n}\right)$. This indicated that other processes were important for nitrate reduction than what could be directly inferred from the isotope pairing technique or the nitrate fluxes alone. DNRA is an alternative pathway for nitrate removal and ammonium formation (Table 2). It is thought to be most prominent at low nitrate and high organic carbon concentrations (Sørensen 1978, Hattori 1983), i.e. conditions similar to the Baltic Sea sediments used in this experiment. In these environments, DNRA may compete with denitrification for nitrate in the pore water as well as for nitrate supplied from the overlying water. Due to the reducing conditions and the high concentrations of ammonium in the pore water (100 to $500 \mu \mathrm{M}$, Fig. 4C), biomass incorporation of nitrate as a $\mathrm{N}$ source is less likely. Assuming nitrate assimilation to be insignificant for nitrate reduction in these sediments, the balance between benthic nitrification and DNRA could be estimated from the nitrate flux and total denitrification (Table 2). Calculations revealed that nitrate reduced through the pathway of DNRA in the sediment was by far more important for nitrate reduction than coupled nitrification/denitrification in the sediment (Fig. 10, Table 2). Denitrification was suppressed relative to DNRA in all cores, including the control; $5 \%$ or less of the nitrate flux from the overlying water to the sediment proceeded through denitrification, while the remaining nitrate was reduced to ammonium in a dissimilatory fashion and thus, contributed to rates of ammonium production in the sediment. The main pathway of benthic $\mathrm{N}$ cycling in the highly reducing sediments of the Baltic Sea thus seemed to include overlying water nitrate as an inorganic N source of ammonium.

Benthic N mineralisation, calculated from the balance of benthic ammonium and nitrate fluxes and total denitrification rate (Table 2), was significantly lower than could be initially inferred from the benthic fluxes of ammonium and nitrate. For example, mass balance calculations indicated that almost no ammonium was produced from organic $\mathrm{N}$ in the control cores. Although rates of mineralisation were low with relatively large variations between replicates, there seemed to be a stimulatory effect from macrofaunal activities in the investigated sediments (Table 2). Stimulation was most pronounced for additions of Macoma balthica (2.1 mmol $\mathrm{N} \mathrm{m}^{-2} \mathrm{~d}^{-1}$ for the $M$. balthica manipulated cores compared to $76 \mu \mathrm{mol} \mathrm{N} \mathrm{m}{ }^{-2} \mathrm{~d}^{-1}$ for the control). However, a mass balance approach to estimate rates of $\mathrm{N}$-mineralisation includes the difficulty of distinguishing ammonium excretion by macrofauna from ammonium produced during organic matter mineralisation. Contribution from ammonium excreted by the macrofauna added to the cores was most likely most pronounced for the bivalve $M$. balthica.

\section{CONCLUSIONS}

The sediments used in the experiments seemed toxic to some of the specimens, but not to all. This suggested that pore-water sulphide was at the border of tolerance for the different species. Particularly, the top millimetres or centimetres of the sediment seemed to be gradually less toxic as the experiment progressed. Thus, we suggest that the surface sediment gradually recovered from the initial sulphidic conditions in treatments where animal recolonisation was possible, and that the experiment therefore resembled a possible natural event.

The survival of Monoporeia affinis increased with time of incubation and reworking of the sediment, probably due to efficient irrigation and the subsequent oxidation of the surrounding sediment. Relatively efficient irrigation of the uppermost centimetres in the $M$. affinis cores was supported by visual observations of a brownish colour and a fluffy texture, low phosphate concentrations and a subsurface mobilisation of nitrate in this sediment layer. Similar observations were not made in the Macoma balthica and the Marenzelleria viridis cores. 
Additions of macrofauna affected rates and pathways of organic matter mineralisation in the reducing Baltic Sea sediments. For example, silicate fluxes in the Monoporeia affinis, the Macoma balthica and the Marenzelleria viridis cores were on average 61, 66 and $45 \%$ larger than the control cores, while oxygen fluxes were on average enhanced by 63, 107 and $43 \%$, respectively.

As a consequence of the highly reducing sediments, pore-water nitrate concentrations were low, promoting the transport of nitrate from the overlying water to the sediment. Denitrification using nitrate supplied from the overlying water $\left(D_{w}\right)$ was also found to be more important than coupled nitrification/denitrification $\left(D_{n}\right)$ in the Monoporeia affinis cores. This observation supports an active transport of overlying water that is injected into the sediment during macrofaunal irrigation.

Low rates of denitrification, despite high fluxes of nitrate into the sediment, indicate additional pathways of nitrate reduction. Mass balance calculations revealed that the pathway of DNRA seemed by far more important for nitrate reduction than sediment denitrification. This observation was supported by the high rates of benthic ammonium fluxes. The main pathway of benthic $\mathrm{N}$ cycling in the highly reducing sediments of the Baltic Sea seemed to include overlying water nitrate as an inorganic $\mathrm{N}$ source of ammonium rather than ammonium production during organic matter mineralisation.

Acknowledgements. We gratefully acknowledge P. Jonsson and the crew aboard the RV 'Sunbeam'; J. Svensson for help and advice during planning and performance of the experiment; F. Gilbert, P. Engström and B. Hellman for assistance during sampling; J. Hollander for statistical support; and J. Bjelvenmark and J. Strickner for help with figures. Financial support was obtained from The Swedish Research Council (VR) and The Foundation for Strategic Environmental Research (MISTRA), The Swedish Research Council for Environment, Agricultural Sciences and Spatial Planning (FORMAS). This work is part of the Swedish research program MARE (Marine Research on Eutrophication).

\section{LITERATURE CITED}

Aller RC (2001) Transport and reactions in the bioirrigated zone. In: Boudreau B, Jørgensen BB (eds) The benthic boundary layer: transport processes and biogeochemistry. Oxford University Press, Oxford, p 269-301

Aller RC, Aller JY (1998) The effect of biogenic irrigation intensity and solute exchange on diagenetic reaction rates in marine sediments. J Mar Res 56:905-936

Aller RC, Yingst JY (1985) Effects of marine deposit-feeders Heteromastus filiformis (Polychaeta), Macoma balthica (Bivalvia), and Tellina texana (Bivalvia) on averaged sedimentary solute transport, reaction rates, and microbial distributions. J Mar Res 43:615-645

Anschutz P, Sundby B, Lefrançois L, Luther IGW, Mucci A
(2000) Interactions between metal oxides and species of nitrogen and iodine in bioturbated marine sediments. Geochim Cosmochim Ac 64:2751-2763

Baden SP, Loo LO, Pihl L, Rosenberg R (1990) Effects of eutrophication on benthic communities including fishSwedish west coast. Ambio 19:113-122

Berner RA (1980) Early diagenesis: a theoretical approach, Princeton University Press, Princeton, NJ

Blackburn TH (1983) The microbial nitrogen cycle. In: Krumbein WE (ed) Microbial geochemistry. Blackwell Scientific Publications, Oxford, p 63-89

Bonsdorff E, Pearson TH (1999) Variation in the sublittoral macrozoobenthos of the Baltic Sea along environmnal gradients: a functional-group approach. Aust J Ecol 24: 312-326

Bonsdorff E, Diaz RJ, Rosenberg R, Norkko A, Cutter Jr GR (1996) Characterization of soft-bottom benthic habitats of the Åland Islands, northern Baltic Sea. Mar Ecol Prog Ser 142:235-245

Boudreau BP (1997) Diagenetic models and their implementation. Springer-Verlag, Berlin

Brune A, Frenzel P, Cypionka H (2000) Life at the oxic-anoxic interface: microbial activities and adaptations. FEMS Microbiol Rev 24:691-710

Carman R, Jonsson P (1991) Distribution patterns of different forms of phosphorus in some surficial sediments of the Baltic Sea. Chem Geol 90:91-106

Christensen PB, Rysgaard S, Sloth NP, Dalsgaard T, Schwærter S (2000) Sediment remineralization, nutrient fluxes, denitrification and dissimilatory nitrate reduction in an estuarine fjord with sea cage trout farms. Aquat Microb Ecol 21:73-84

Diaz RJ, Rosenberg R (1995) Marine benthic hypoxia: a review of its ecological effects and behavioural responses of benthic macrofauna. Oceanogr Mar Biol Annu Rev 33: 245-303

Diaz RJ, Schaffner LC (1990) The functional role of estuarine benthos. In: Haire M, Krome EC (eds) Perspectives on the Chesapeake Bay, 1990 advances in estuarine sciences. Chesapeake Research Consortium, Gloucester Pt., VA, p 25-56

Elmgren R (1989) Man's impact on the ecosystem of the Baltic Sea: energy flows today and at the turn of the century. Ambio 18:326-332

Froelich PN, Klinkhammer GP, Bender ML, Luedtke NA and 6 others (1979) Early oxidation of organic matter in pelagic sediments of the eastern equatorial Atlantic: suboxic diagenesis. Geochim Cosmochim Acta 43:1075-1090

Gerlach SA (1994) Oxygen conditions improve when the salinity in the Baltic Sea decreases. Mar Pollut Bull 28: 413-416

Gilbert F, Stora G, Bonin P (1998) Influence of bioturbation on denitrification activity in Mediterranean coastal sediments: an in situ experimental approach. Mar Ecol Prog Ser 163:99-107

Gilbert F, Aller RC, Hulth S (2003) The influence of biogenic irrigation intensity on benthic nitrification and denitrification: an experimental and model approach. J Mar Res 61: 101-125

Gran V, Pitkänen H (1999) Denitrification in estuarine sediments in the eastern Gulf of Finland, Baltic Sea. Hydrobiologia 393:107-115

Hagerman L, Sandberg E, Vismann B (1997) Oxygen-binding properties of haemolymph from the benthic amphipod Monoporeia affinis from the Baltic. Mar Biol 130:209-212

Hattori A (1983) Denitrification and dissimilatory nitrate reduction. In: Carpenter E, Capone DB (eds) Nitrogen in 
the marine environment. Academic Press, San Diego, CA, p 191-232

Henriksen K, Kemp MW (1988) Nitrification in estuarine and coastal marine sediments. In: Blackburn TH, Sørensen J (eds) Nitrogen cycling in coastal environments. WileyLiss, New York, p 207-273

Hill C, Elmgren R (1987) Vertical distribution in the sediment in the co-occurring benthic amphipods Pontoporeia affinis and P. femorata. Oikos 49:221-229

Hulth S (1995) Mineralization of biogenic debris in continental shelf and slope sediments. PhD thesis, Göteborg University

Hulth S, Aller RC, Gilbert F (1999) Coupled anoxic nitrification/manganese reduction in marine sediments. Geochim Cosmochim Acta 63:49-66

Hulth S, Engström P, Selander E, Aller RC (2002) A pH plate fluorosensor for early diagenetic studies of marine sediments. Limnol Oceanogr 47:212-220

Hulth S, Aller RC, Canfield DE, Dalsgaard T, Gilbert F, Sundbäck K, Thamdrup B (2005) Nitrogen removal in marine environments: recent developments and future research challenges. Mar Chem 94:125-145

Hulthe G, Hulth S, Hall POJ (1997) Effect of oxygen on degradation rate of refractory and labile organic matter in continental margin sediments. Geochim Cosmochim Acta 62: $1319-1328$

Hyllenberg J, Henriksen H (1980) The central role of bioturbation in sediment mineralization and element re-cycling. Ophelia 1:1-16

Jahn A, Theede H (1997) Different degrees of tolerance to hydrogen sulphide in populations of Macoma balthica (bivalvia, Tellinidae). Mar Ecol Prog Ser 154:185-196

Jahn A, Janas U, Theede H, Szaniawska A (1997) Significance of body size in sulphide detoxification in the Baltic calm Macoma balthica (Bivalvia, Tellinidae) in the Gulf of Gdansk. Mar Ecol Prog Ser 154:175-183

Jonsson P, Carman R, Wulff F (1990) Laminated sediments in the Baltic - a tool for evaluating nutrient mass balances. Ambio 19:152-158

Jørgensen BB (1977) Distribution of colorless sulfur bacteria (Beggiatoa spp.) in a coastal marine sediment. Mar Biol 41: $19-28$

Karlson K, Rosenberg R, Bonsdorff E (2002) Temporal and spatial large-scale effects of eutrophication and oxygen deficiency on benthic fauna in Scandinavian and Baltic waters - a review. Oceanogr Mar Biol Annu Rev 40: 427-489

Kristensen E, Hjorth Jensen M, Aller RC (1991) Direct measurements of dissolved inorganic nitrogen exchange and denitrification in individual polychaete (Nereis virens) burrows. J Mar Res 49:355-377

Krom MD, Berner RA (1980) Adsoption of phosphate in anoxic marine sediments. Limnol Oceanogr 25:797-806

Lännergren C, Eriksson B (2000) Undersökningar i Stockholms skärgårdsområde. Report No. MV-00115. Stockholm Vatten AB, Stockholm

Laine AO (1999) Long-term changes of macrozoobenthos in relation to environmental variability in the open Baltic Sea. Department of Ecology and Systematics, Tvärminne Zoological Station, Tvärminne

Laine AO, Sandler H, Andersin AB, Stigzelius J (1997) Longterm changes of macrozoobenthos in the eastern Gotland basin and the Gulf of Finland (Baltic Sea) in relation to the hydrographical regime. J Sea Res 38:135-159

Larsson U, Elmgren R, Wulff F (1985) Eutrophication and the Baltic Sea: causes and consequences. Ambio 14:9-14

Leppäkoski E (1971) Benthic recolonization of the Bornholm basin (Southern Baltic) in 1969-71. Thalassia Jugosl 7 171-179

Lindström M (1991) Factors affecting the horizontal migration of the amphipode Pontoporeia affinis Lindström. I. Recording method and response to water currents. J Exp Mar Biol Ecol 150:149-162

Lopez G, Elmgren R (1989) Feeding depths and organic absorption for the deposit-feeding benthic amphipods Pontoporeia affinis and Pontoporeia femorata. Limnol Oceanogr 34:982-991

Luther GWI, Sundby B, Lewis BL, Brendel PJ, Silverberg N (1997) Interactions of manganese with the nitrogen cycle: alternative pathways to dinitrogen. Geochim Cosmochim Acta 61:4043-4052

Magni P, Montani S, Takada C, Tsutsumi H (2000) Temporal scaling and relevance of bivalve nutrient excretion on a tidal flat of the Seto Inland Sea, Japan. Mar Ecol Prog Ser 198:139-155

Mayer MS, Schaffner L, Kemp WM (1995) Nitrification potentials of benthic macrofaunal tubes and burrow walls: effects of sediment $\mathrm{NH}_{4}{ }^{+}$and animal irrigation behavior. Mar Ecol Prog Ser 121:157-169

Modig H, Ólafsson E (2001) Survival and bioturbation of the amphipod Monoporeia affinis in sulphide-rich sediments. Mar Biol 138:87-92

Mortimer RJG, Davey JT, Krom MD, Watson PG, Frickers PE, Clifton RJ (1999) The effect of macrofauna on porewater profiles and nutrient fluxes in the intertidal zone of the Humber Estuary. Estuar Coast Shelf Sci 48:683-699

Nielsen LP (1992) Denitrification in sediment determined from nitrogen isotope pairing. FEMS Microbiol Ecol 86:357-362

Ólafsson EB (1986) Density dependence in suspension-feeding and deposit-feeding populations of the bivalve Macoma baltica: a field experiment. J Anim Ecol 55:517-526

Olenin S, Leppäkoski E (1999) Non-native animals in the Baltic Sea: alternation of benthic habitats in coastal inlets and lagoons. Hydrobiologia 393:233-243

Pearson TH, Rosenberg R (1978) Macrobenthic succession in relation to organic enrichment and pollution of marine environment. Oceanogr Mar Biol Annu Rev 16:229-311

Pearson TH, Rosenberg R (1987) Feast and famine: structuring factors in marine benthic communities. In: Gee JHR, Giller PS (eds) The 27th symposium of the British Ecological Society, Aberystwyth 1986. Blackwell Scientific Publications, Oxford, p 373-395

Pelegrí SP, Blackburn TH (1995) Effect of bioturbation by Nereis sp., Mya arenaria and Cerastoderma sp. on nitrification and denitrification in estuarine sediments. Ophelia 42:289-299

Pelegrí SP, Nielsen LP, Blackburn TH (1994) Denitrification in estuarine sediment stimulated by the irrigation activity of the amphipod Corophium volutator. Mar Ecol Prog Ser 105:285-290

Persson J, Jonsson P (2000) Historical development of laminated sediments - an approach to detect soft sediment ecosystem changes in the Baltic Sea. Mar Pollut Bull 40: $122-134$

Reise K (1983) Biotic enrichment of intertidal sediments by experimental aggregates of the deposit-feeding bivalve Macoma baltica. Mar Ecol Prog Ser 12:229-236

Risgaard-Petersen N, Nielsen L, Rysgaard S, Dalsgaard T, Meyer R (2003) Application of the isotope pairing technique in sediments where anammox and denitrification coexist. Limnol Oceanogr: Methods 1:63-73

Rumohr H, Bonsdorff E, Pearson TH (1996) Zoobenthic succession in Baltic sedimentary habitats. Arch Fish Mar Res $44: 179-214$ 
Sandberg-Kilpi E, Vismann B, Hagerman L (1999) Tolerance of the baltic amphipod Monoporeia affinis to hypoxia, anoxia and hyrogen sulfide. Ophelia 50:61-68

Schiedek D (1997) Marenzelleria viridis (Verrill, 1873) (Polychaeta), a new benthic species within European coastal waters: some metabolic features. J Exp Mar Biol Ecol 211: 85-101

Skoog A, Hall POJ, Hulth S, Paxéus N, Rutgers van der Loeff M, Westerlund S (1996) Early diagenic production and sediment-water exchange of fluorescent dissolved organic matter in the coastal environment. Geochim Cosmochim Acta 60:3619-3629

Sørensen J (1978) Capacity for denitrification and reduction of nitrate to ammonia in a coastal marine sediment. Appl Environ Microb 35:301-305

Steingruber S, Freidrich J, Gächter R, Wehrli B (2001) Measurements of denitrification in sediments with the $15 \mathrm{~N}$ isotope pairing technique. Appl Environ Microb 67:3771-3778

Strickland JDH, Parsons TR (1972) A practical handbook of sea water analysis. Bull Fish Res Board Can 169:1-311

Sundby B, Anderson LG, Hall POJ, Iverfeldt $\AA$, Rutgers van der Loeff MM, Westerlund SFG (1986) The effect of oxygen on release and uptake of cobalt, manganese, iron and phosphate at the sediment-water interface. Geochim Cosmochim Acta 50:1281-1288

Svensson JM, Leonardson L (1996) Effects of bioturbation by tube-dwelling chironomid larvae on oxygen uptake and

Editorial responsibility: Otto Kinne (Editor-in-Chief), Oldendorf/Luhe, Germany denitrification in eutrophic lake sediments. Freshw Biol 35:289-300

Thamdrup B (2000) Bacterial manganese and iron reduction in aquatic sediments. Adv Microb Ecol 16:41-83

Trueman ER, Ansell AD (1969) The mechanisms of burrowing into soft subtrata by marine animals. Oceanogr Mar Biol Annu Rev 7:315-366

Tuominen L, Mäkelä K, Lehtonen K, Haahti H, Hietanen S, Kupariene J (1999) Nutrients fluxes, porewaterprofiles and denitrification in sediment influenced by algal sedimentation and bioturbation by Monoporeia affinis. Estuar Coast Shelf S 49:83-97

Underwood AJ (1997) Experiments in ecology: their logical design and interpretation using analysis of variance. Cambridge University Press, Cambridge

Ward BB (2000) Nitrification and the marine nitrogen cycle. In: Kirchman DL (ed) Microbial ecology of the oceans. Wiley-Liss, New York, p 427-453

Wulff F, Stigebrandt A (1989) A time dependent budget model for nutrients in the Baltic Sea. Global Biogeochem Cycles 3:63-78

Zettler ML (1997) The newcomer Marenzelleria viridis (Verrill, 1873), its development and influence on the indigenous macrozoobenthos in a coastal water of southern Baltic. In: Ojaveer E (ed) Proceedings of the 14th Baltic Marine Biologist Symposium. Estonian Academy Publishers, Pärnu, p 280-296

Submitted: September 28, 2004; Accepted: February 17, 2005 Proofs received from author(s): May 17, 2005 